Article

\title{
Oryzines A \& B, Maleidride Congeners from Aspergillus oryzae and Their Putative Biosynthesis
}

\author{
Zahida Wasil ${ }^{1}$, Eric Kuhnert ${ }^{2}$, Thomas J. Simpson ${ }^{3}$ (i) and Russell J. Cox ${ }^{4, *}$ \\ 1 University of Bristol, School of Chemistry, Cantock's Close, Bristol BS8 1TS, UK; zahida.wasil@gmail.com \\ 2 Leibniz Universität Hannover, Biomolekulares Wirkstoffzentrum und Institut für Organische Chemie, \\ Schneiderberg 38, 30167 Hannover, Germany; eric.kuhnert@oci.uni-hannover.de \\ 3 University of Bristol, School of Chemistry, Cantock's Close, Bristol BS8 1TS, UK; Tom.Simpson@bristol.ac.uk \\ 4 Leibniz Universität Hannover, Biomolekulares Wirkstoffzentrum und Institut für Organische Chemie, \\ Schneiderberg 38, 30167 Hannover, Germany \\ * Correspondence: russell.cox@oci.uni-hannover.de; Tel.: +49-511-762-16301
}

Received: 19 July 2018; Accepted: 10 August 2018; Published: 13 August 2018

\begin{abstract}
Aspergillus oryzae is traditionally used in East Asia for the production of food and brewing. In addition, it has been developed into a suitable host for the heterologous expression of natural product biosynthetic genes and gene clusters, enabling the functional analysis of the encoded enzymes. A. oryzae shares a $99.5 \%$ genome homology with Aspergillus flavus, but their secondary metabolomes differ significantly and various compounds unique to $A$. oryzae have been reported. While using $A$. oryzae as a host for heterologous expression experiments we discovered two new metabolites in extracts of $A$. oryzae M-2-3 with an unusual maleidride backbone, which were named oryzine A and B. Their structures were elucidated by high resolution mass spectrometry (HRMS) and nuclear magnetic resonance (NMR) analysis. Their structural relationships with known maleidrides implied involvement of a citrate synthase (CS) and a polyketide (PKS) or fatty acid synthase (FAS) in their biosynthesis. Analysis of the A. oryzae genome revealed a single putative biosynthetic gene cluster (BGC) consistent with the hypothetical biosynthesis of the oryzines. These findings increase knowledge of the chemical potential of $A$. oryzae and are the first attempt to link a novel product of this fungus with genomic data.
\end{abstract}

Keywords: natural products; citrate synthase; biosynthetic gene cluster; structure elucidation; fatty acid synthase

\section{Introduction}

Aspergillus oryzae is a filamentous fungus widely used in the food production industry of many East Asian countries to ferment soy beans as basis for soy sauces, miso and fermented bean paste, but also for brewing of various beverages [1]. In addition, enzymes used in food processing, such as $\alpha$-amylases, aminopeptidases, lactases, lipases or proteases, are isolated in large scale from A. oryzae [2]. Due to its economic importance the fungus has been extensively studied and genetic tools became readily available to manipulate the organism. In combination with its advantageously limited set of native compounds $A$. oryzae has been successfully developed as a heterologous expression system for fungal secondary metabolites [2,3]. This system has been important in the discovery and functional analysis of various biosynthetic gene clusters (BGC) including xenovulenes, pleuromutilins, maleidrides and aphidicolin [4-7].

Whole genome sequencing of the RIB40 strain of A. oryzae and other Aspergillus species revealed a $99.5 \%$ similarity between the genomes of Aspergillus flavus and A. oryzae. Therefore, it has been suggested that the latter is a domesticated variety of $A$. flavus, mainly differing in the lack of aflatoxin 
production [8]. An in-depth chemical comparison between the two species showed striking differences in the metabolites produced. Thus, A. oryzae produces kojic acid, the diterpene indoles aflavinines, the aflatrem precursor 13-desoxypaxilline, the sesquiterpenes parasiticolides and various alkaloids, e.g., ditryptoleucine and oryzamides [9]. Other compounds produced by A. oryzae have been reported recently [10-12]. However, identifications of the respective producing strains were solely based on morphological characteristics and ribosomal genes, which are insufficient to clearly differentiate them from A. flavus [13]. Even though the genome sequence of $A$. oryzae has been available since 2005 [14], only the BGCs of aflatoxin, cyclopiazonic acid, aflatrem, kojic acid, 3, 5-dihydroxybenzoic acid and penicillin have been identified [9,15-17]. This is a small number compared with the 32 annotated polyketide synthase (PKS) and 27 annotated non-ribosomal peptide synthetase (NRPS) BGCs of A. oryzae, and leaves much room for new findings [9].

In this study, we report the identification and structure elucidation of two new secondary metabolites of the maleidride family produced by A. oryzae M-2-3 [18]. In addition, a candidate BGC encoded by the genome of $A$. oryzae is bioinformatically characterized and a putative biosynthetic pathway is presented.

\section{Materials and Methods}

\subsection{General}

Optical rotations were determined with an ADP 220 polarimeter at $589 \mathrm{~nm}$ and IR spectra were recorded with a Perkin-Elmer FTIR instrument. NMR spectra were recorded on a Varian VNMRS-500 spectrometer $\left({ }^{1} \mathrm{H} 500 \mathrm{MHz},{ }^{13} \mathrm{C} 125 \mathrm{MHz}\right)$. HR-ESI-MS mass spectra were determined with a Bruker Daltonics Apex IV FT-ICR. HPLC analysis was performed on a Waters 2795HT HPLC system. Detection was achieved by UV between 200 and $400 \mathrm{~nm}$ using a Waters 998 diode array detector, and by simultaneous electrospray (ES) mass spectrometry using a Waters ZQ spectrometer detecting between 150 and $600 \mathrm{~m} / z$ units. Chromatography (flow rate $1 \mathrm{~mL} / \mathrm{min}$ ) was performed using a Phenomenex Kinetex column $\left(2.6 \mu, C_{18}, 100 \AA, 4.6 \times 100 \mathrm{~mm}\right)$ equipped with a Phenomenex Security Guard precolumn (Luna $\mathrm{C}_{5} 300 \AA$ ). The mobile phase consisted of solvent A (HPLC grade $\mathrm{H}_{2} \mathrm{O}$ containing $0.05 \%$ formic acid) and solvent $\mathrm{B}$ (HPLC grade $\mathrm{CH}_{3} \mathrm{CN}$ containing $0.045 \%$ formic acid) subjected to the following gradient: $0 \mathrm{~min}, 10 \% \mathrm{~B} ; 10 \mathrm{~min}, 90 \% \mathrm{~B} ; 12 \mathrm{~min}, 90 \% \mathrm{~B} ; 13 \mathrm{~min}, 10 \% \mathrm{~B} ; 15 \mathrm{~min}, 10 \% \mathrm{~B}$.

\subsection{Fermentation and Extraction}

Three liters of $A$. oryzae M-2-3 pTAex3-tenS(8309).egfp [19] (30 flasks $\times 100 \mathrm{~mL}$ ) were grown in production medium $\left(20 \mathrm{~g} / \mathrm{L}\right.$ starch, $10 \mathrm{~g} / \mathrm{L}$ peptone, $2 \mathrm{~g} / \mathrm{L} \mathrm{NaNO}_{3}, 2 \mathrm{~g} / \mathrm{L} \mathrm{KCl}, 1 \mathrm{~g} / \mathrm{L} \mathrm{K}_{2} \mathrm{HPO}_{4}$, $0.5 \mathrm{~g} \mathrm{MgSO}_{4} .7 \mathrm{H}_{2} \mathrm{O}, 0.01 \mathrm{~g} \mathrm{FeSO}_{4} .7 \mathrm{H}_{2} \mathrm{O}$ ) for 6 days at $28^{\circ} \mathrm{C}$ and shaken at $200 \mathrm{rpm}$. Cells and media were homogenized using a hand-held electric blender and then acidified to $\mathrm{pH} 4.0$ using $37 \%$ aqueous $\mathrm{HCl}$. An equal volume of ethyl acetate was added and the mixture was stirred for $10 \mathrm{~min}$. and then vacuum filtered through Whatman no. 1 filter paper. The filtrate was transferred into a separating funnel and shaken vigorously. The organic layer was washed once with concentrated brine solution and then with deionized water. The organic phase was dried $\left(\mathrm{MgSO}_{4}\right)$, filtered and evaporated to dryness. The crude extract was dissolved in $10 \%$ aqueous methanol and defatted by extraction with hexane. The methanolic layer was evaporated to dryness to yield crude extract $(239 \mathrm{mg})$ and analyzed by liquid chromatography mass spectrometry (LCMS).

\subsection{Isolation of Oryzine A 3 and Oryzine B 4}

The crude extract was dissolved in HPLC grade methanol and subjected to mass-directed preparative HPLC. Purification of compounds was achieved using a Waters mass-directed auto-purification system comprising of a Waters 2767 autosampler, Waters 2545 pump system, a Phenomenex LUNA column $\left(5 \mu, C_{18}, 100 \AA, 10 \times 250 \mathrm{~mm}\right)$ equipped with a Phenomenex Security Guard precolumn (Luna $C_{5} 300 \AA$ ) eluted at $16 \mathrm{~mL} / \mathrm{min}$. Solvents used were: A, HPLC grade 
$\mathrm{H}_{2} \mathrm{O}+0.05 \%$ formic acid; $\mathrm{B}$, HPLC grade $\mathrm{CH}_{3} \mathrm{CN}+0.045 \%$ formic acid. The post-column flow was split (100:1) and the minority flow was made up with solvent $\mathrm{A}$ to $1 \mathrm{~mL} / \mathrm{min}$ for simultaneous analysis by diode array detector (Waters 2998; Milford, MA, USA), evaporative light scattering (Waters 2424; Milford, MA, USA) and ESI mass spectrometry in positive and negative modes (Waters Quatro Micro; Milford, MA, USA). The gradient started with $40 \%$ to $80 \%$ B over $15 \mathrm{~min}$, continued for $0.5 \mathrm{~min}$ to $95 \%$ and ended with $1 \mathrm{~min}$ isocratic conditions. Fractions of 24 consecutive runs were combined to yield $9.5 \mathrm{mg}$ of 3 and $9.0 \mathrm{mg}$ of 4 .

\subsection{Spectroscopic and Spectrometric Data}

The corresponding 1D and 2D NMR spectra of 3 and 4 are depicted in the Supplementary Information (Figures S1-S10).

\subsubsection{Oryzine A 3}

Light brown viscous oil, $[\alpha]^{22} \mathrm{D}-16.9(c=0.23, \mathrm{MeOH})$; IR (neat): $v_{\max } 2932,2872,2342,1761$, $1631,1355,1190,1084 \mathrm{~cm}^{-1} ;{ }^{1} \mathrm{H}$ NMR $\left(\mathrm{CDCl}_{3}, 500 \mathrm{MHz}\right) \delta=0.92(3 \mathrm{H}, \mathrm{t}, J=7 \mathrm{~Hz}, \mathrm{H}-1), 1.36(2 \mathrm{H}, \mathrm{m}$, H-2), 1.37 (1 H, m, H-3a), 1.45 (1 H, m, H-3b), $1.65(1 \mathrm{H}, \mathrm{m}, \mathrm{H}-4 \mathrm{a}), 1.81(1 \mathrm{H}, \mathrm{m}, \mathrm{H}-4 \mathrm{~b}), 2.01(1 \mathrm{H}, \mathrm{ddd}$, $J=12,10.5,12 \mathrm{~Hz}, \mathrm{H}-6 \mathrm{a}), 2.55(1 \mathrm{H}, \mathrm{ddd}, J=9,6,12 \mathrm{~Hz}, \mathrm{H}-6 \mathrm{~b}), 3.65(1 \mathrm{H}, \mathrm{t}, J=9,12 \mathrm{~Hz}, \mathrm{H}-7), 4.43(1 \mathrm{H}$, m, H-5), 5.95 (1 H, b, H-10a), 6.54 (1 H, b, H-10b), ${ }^{13} \mathrm{C} \mathrm{NMR}\left(\mathrm{CDCl}_{3}, 125 \mathrm{MHz}\right) \delta=14.4(\mathrm{C}-1), 22.9$ (C-2), 27.8 (C-3), 35.5 (C-4), 36.1 (C-6), 45.2 (C-7), 79.6 (C-5), 131.8 (C-10), 136.1 (C-8), 170.1(C-9), 176.4 (C-11). HRESIMS calculated for $\mathrm{C}_{11} \mathrm{H}_{17} \mathrm{O}_{4}$ : 213.1121; observed $213.1130[\mathrm{M}+\mathrm{H}]^{+}$.

\subsubsection{Oryzine B 4}

Light color viscous oil, IR (neat): $v_{\max } 2962,2930,2873,1736,1582,1454,1045,878 \mathrm{~cm}^{-1},{ }^{1} \mathrm{H}$ NMR $\left(\mathrm{CDCl}_{3}, 500 \mathrm{MHz}\right) \delta=0.92(3 \mathrm{H}, \mathrm{t}, J=7 \mathrm{~Hz}, \mathrm{H}-1), 1.38(2 \mathrm{H}, \mathrm{m}, \mathrm{H}-2), 1.46(2 \mathrm{H}, \mathrm{m}, \mathrm{H}-3), 1.71(1 \mathrm{H}$, m, H-4a), $1.791 \mathrm{H}, \mathrm{m}, \mathrm{H}-4 \mathrm{~b}), 4.99(1 \mathrm{H}, \mathrm{t}, J=6.2 \mathrm{~Hz}, \mathrm{H}-5), 6.79$ (1 H, b, H-10a), $7.19(1 \mathrm{H}, \mathrm{b}, \mathrm{H}-10 \mathrm{~b})$, $7.96(1 \mathrm{H}, \mathrm{b}, \mathrm{H}-6) ;{ }^{13} \mathrm{C}$ NMR $\left(\mathrm{CDCl}_{3}, 125 \mathrm{MHz}\right) \delta=14.0(\mathrm{C}-1), 22.6$ (C-2), 27.3 (C-3), 33.1 (C-4), 80.8 (C-5), 125.0 (C-7), 128.5 (C-8), 133.6 (C-10), 153.5 (C-6), 169.5 (C-9), 171.7 (C-11). HRESIMS calculated for $\mathrm{C}_{11} \mathrm{H}_{14} \mathrm{O}_{4} \mathrm{Na}$ : 233.0784; observed $233.0799[\mathrm{M}+\mathrm{Na}]^{+}$.

\subsection{Oryzine Biosynthetic Gene Cluster Prediction}

The prediction of the BGC responsible for oryzine production is based on the genome information available for A. oryzae RIB40 (BioProject: PRJNA28175). The producing strain of the oryzines (M-2-3) is an auxotrophic mutant derived from A. oryzae RIB203, which is genetically very close to RIB40 (https:/ / www.nrib.go.jp/data/asp/strain.html). Due to annotation gaps a part of the genome was re-annotated. Gene prediction was accomplished by applying AUGUSTUS version 3.3. [20] on the A. oryzae RIB40 chromosome 8 (RefSeq: NC_036442.1) using the precomputed gene model for this species. For comparison purpose, in addition, GeneMark-ES version 4.3.3. [21] was applied by using the parameters for self-training (-ES) and fungal genomes (-fungus). Clustered genes in A. oryzae related to the byssochlamic acid BGC from Byssochlamys fulva were identified with the MultiGeneBlast architecture search [22] using bfpks1, bfl2 and bfl3 [6] as templates. Homologies of the putative oryzine BGC with related BGCs from A. flavus NRRL 3357 and B. fulva were analyzed with the Artemis comparison tool (ACT) [23].

\section{Results}

As part of a larger project involving the use of A. oryzae M-2-3 [18] as a host for the heterologous expression of engineered fungal polyketide synthase genes, we were interested in the biosynthesis of pretenellin A 1. This compound is produced by the tenellin synthetase (TENS) which is a hybrid polyketide synthase non-ribosomal peptide synthetase (PKS-NRPS) which works with a trans-acting enoyl reductase, encoded by ten $C$ or $d m b C$ [24,25]. We engineered a system containing a truncated tenS 
gene, lacking the sequence encoding the NRPS, together with $d m b C$ [19]. We predicted that this would produce the tenellin polyketide 2 with nominal mass $210 \mathrm{Da}$. Comparison of transformed (Figure 1C,D) vs WT A. oryzae M-2-3 (Figure 1A,B) revealed the presence of a new compound (RT $30.3 \mathrm{~min}$ ) in the transformed strain with the expected nominal mass (Figure 1D, $[\mathrm{M}+\mathrm{H}]^{+}$211.1). This was accompanied by a compound (RT $29.0 \mathrm{~min},[\mathrm{M}+\mathrm{H}]^{+}$213.1) which is present in both WT and transformed strains, although at significantly lower titer in the WT strain $(<1 \%)$. Both compounds were purified from extracts of the transformed A. oryzae strain by mass-directed HPLC. Full structure elucidation (vide infra) revealed these two compounds to be unrelated to pretenellin A 1 , showing that the original experiment had failed.
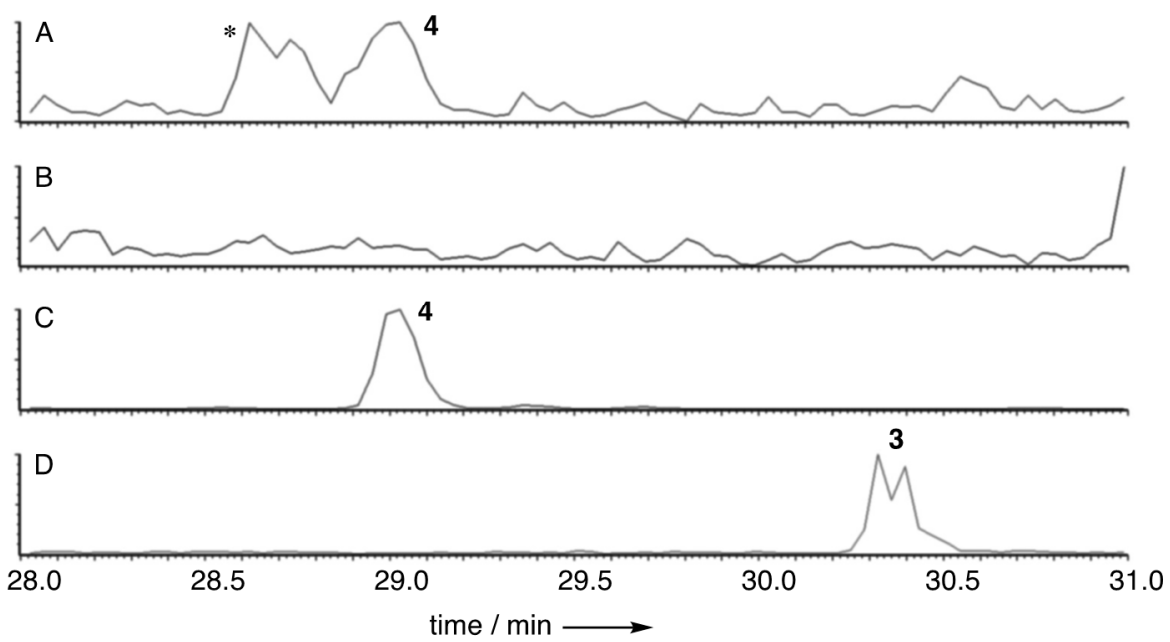

Figure 1. LCMS analysis of extracts of A. oryzae. (A) WT A. oryzae M-2-3, extracted ion chromatogram $\left(\mathrm{EIC}^{+}\right.$) for $\mathrm{m} / \mathrm{z} 213.1$ (oryzine B 4, $[\mathrm{M}+\mathrm{H}]^{+}$); (B) WT A. oryzae M-2-3, EIC ${ }^{+}$for $\mathrm{m} / \mathrm{z} 211.1$ (oryzine A 3, $[\mathrm{M}+\mathrm{H}]^{+}$); (C) A. oryzae M-2-3 pTAex3-tenS(8309) egfp EIC ${ }^{+}$for $m / z 213.1$ (oryzine B 4, $[\mathrm{M}+\mathrm{H}]^{+}$); (D) A. oryzae M-2-3 pTAex3-tenS(8309).egfp EIC+ for $m / z 211.1$ (oryzine A 3, $[\mathrm{M}+\mathrm{H}]^{+}$). * unrelated compound.

\subsection{Structure Elucidation}

Oryzine A 3 was obtained as light brown viscous oil. The HRESIMS data of 3 indicated a molecular formula of $\mathrm{C}_{11} \mathrm{H}_{17} \mathrm{O}_{4}$ (calc. 213.1121, obs. 213.1130, $[\mathrm{M}+\mathrm{H}]^{+}$). The carbon spectra $(125 \mathrm{MHz})$ revealed the presence of eleven carbons, which included two carbonyl groups at $\delta_{C} 176.4(\mathrm{C}-11)$ and 170.1 (C-9), four methylene groups in the alkane region of the spectra and one methyl carbon at $\delta_{C}$ 14.4 (C-1, Figure 2). The HSQC (heteronuclear single quantum coherence spectroscopy) spectrum revealed 8 protonated carbons. The ${ }^{1} \mathrm{H}$ NMR spectrum showed two distinct doublets in the alkene region at $\delta_{\mathrm{H}} 5.95$ and $\delta_{\mathrm{H}} 6.54$ which were assigned to two geminal methylene protons attached to $\mathrm{C}-10$. One of these methylene protons shows HMBC (heteronuclear multiple bond correlation) correlation to an alkene carbon at $\delta_{C} 136.1$ which was assigned C-8. Both geminal methylene protons $(\mathrm{H}-10)$ show HMBC correlations to $\mathrm{C}-9$ and a methine at $\delta_{\mathrm{C}} 45.2$ (C-7). The triplet at $\delta_{\mathrm{H}} 3.65$ was assigned to a methine proton (H-7) which showed an HMBC correlation to C-11, C-9 and an alkene carbon at $\delta_{\mathrm{C}} 136.1$ (C-8). H-7 shows COSY (correlation spectroscopy) coupling to two geminal methylene protons at $\delta_{\mathrm{H}} 2.01$ and 2.55 (H-6). These, in turn, show COSY and HMBC connections to a methine proton at $\delta_{\mathrm{H}} 4.43(\mathrm{C}-5)$ attached to an oxygen atom. The chemical shift of $\delta_{\mathrm{C}} 79.6$ for C-5 supports its link to an oxygen atom. This data suggested the presence of a pyrone with a carboxylic acid at C-7. The methine protons at $\delta_{\mathrm{H}} 4.43(\mathrm{H}-5)$ and methylene protons at $\delta_{\mathrm{H}} 2.01$ and $2.55(\mathrm{H}-6)$ show COSY connections to two other geminal protons at $\delta_{\mathrm{H}} 1.65$ and $1.81(\mathrm{H}-4)$. Two multiplets at $\delta_{\mathrm{H}}$ 1.37 and 1.46 were assigned to geminal methylene protons $\left(3-\mathrm{CH}_{2}\right)$ which displays a COSY coupling to one of the methylenes at $\delta_{\mathrm{H}} 1.8(\mathrm{H}-4)$. The broad signal at $\delta_{\mathrm{H}} 1.35-1.39$ was assigned to methylene 
protons $\left(2-\mathrm{CH}_{2}\right)$ showing correlations to $\delta_{\mathrm{C}} 27.8(\mathrm{C}-3)$ in the $\mathrm{HMBC}$ spectrum and to the methyl at $\delta_{\mathrm{H}}$ $0.92(\mathrm{H}-1)$. Both HMBC and COSY correlations show an aliphatic chain (C1-C4) attached to the pyran at $\mathrm{C}-5$ methine.

The relative orientation of the protons at the two stereocentres C-5 and C-7 was established using the coupling constants of $\mathrm{H}-5$ and $\mathrm{H}-7$ with their adjacent methylene protons at $\delta_{\mathrm{H}} 2.01$ (H-6a) and $\delta_{\mathrm{H}} 2.55$ (H-6b, Figure 2). A J value of $6 \mathrm{~Hz}$ between $\mathrm{H}-5$ and $\mathrm{H}-6 \mathrm{~b}$ indicated this pair of protons to be gauche, while the J value of $10 \mathrm{~Hz}$ between $\mathrm{H}-5$ and $\mathrm{H}-6$ a suggesting this pair as anti and thus axial/axial. The methine proton $\mathrm{H}-7$ displayed a J value of $12 \mathrm{~Hz}$ with $\mathrm{H}-6 \mathrm{a}$ and $9 \mathrm{~Hz}$ with $\mathrm{H}-6 \mathrm{~b}$. These values suggest that $\mathrm{H}-7$ is also axial.

The structure of 4 was assigned using HRMS and NMR analysis and by comparison to 3 . The chemical formula is $\mathrm{C}_{11} \mathrm{H}_{14} \mathrm{O}_{4}$ (HRMS, observed 233.0799; calculated 233.0784 for [M+ Na] $]^{+}$). The ${ }^{13} \mathrm{C}$ NMR displayed the presence of 11 carbons including two carbonyls at $\delta_{C} 169.5$ (C-9) and $171.7(\mathrm{C}-11)$, a methine carbon at $\delta_{\mathrm{C}} 80.8$ (C-5) attached to an oxygen atom, a methyl group at $\delta_{\mathrm{C}}$ 14.0 (C-1), three methylene groups and four olefinic carbons at $\delta_{C} 125.0$ (C-7), 128.5 (C-8), 133.6 (C-10) and 153.5 (C-6, Figure 2). The HSQC spectrum showed seven protonated carbons. In the ${ }^{1} \mathrm{H}$ NMR, the broad doublet signal downfield at $\delta_{\mathrm{H}} 7.96$ was assigned to the methine $(\mathrm{H}-6)$ attached to the olefinic carbon at $\delta_{C} 153.5$ (C-6) in the HSQC spectrum. In the HMBC spectrum, H-6 shows linkage to methine C-5 and to the olefinic carbon C-7. This confirmed the presence of an olefin between C-6 and C-7. H-6 also shows HMBC correlations with the olefin carbons C-8 and C- 11 . The two broad resonances at $\delta_{\mathrm{H}} 6.79$ and 7.19 were assigned to geminal methylene protons attached to $\mathrm{C}-10$ showing correlations to the methine protons $\mathrm{H}-5$ and $\mathrm{H}-6$ in the COSY, and HMBC correlations to the olefin carbon C-7 and to the C-9 carbonyl. The triplet signal at $\delta_{\mathrm{H}} 4.99$ was assigned to the $\mathrm{H}-5$ methine, displaying HMBC correlations with the methylene groups at $\delta_{\mathrm{C}} 27.3$ (C-3) and 33.1 (C-4) and to olefin carbons C-7 and C-6. The two multiplet signals at $\delta_{\mathrm{H}} 1.71$ and 1.79 were assigned to geminal methylene protons $(\mathrm{H}-4)$ correlated to C-2 and C-3 in the HMBC. The methyl signal at $\delta_{\mathrm{H}} 0.92(\mathrm{H}-1)$ showed HMBC correlations to the methylene groups at $\mathrm{C}-2$ and $\mathrm{C}-3$. This compound was thus assigned the same carbon skelton as oryzine A 3, but unsaturated between C-6 and C-7.

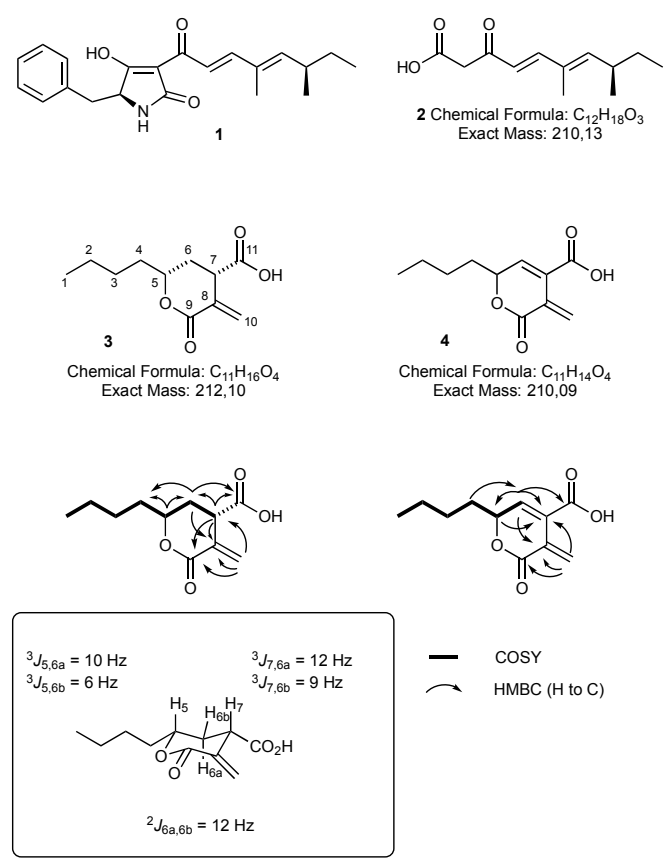

Figure 2. Chemical structures of pretenellin A $\mathbf{1}$ and the predicted product $\mathbf{2}$ of the tenellin PKS. Actual structures of oryzine A 3 and B 4. 


\subsection{Identification of A Putative Oryzine Biosynthetic Gene Cluster}

The structures of the oryzines indicate a biosynthetic relationship to the maleidrides $[6,26,27]$. In general, the biosynthesis of maleidrides is characterized by condensation of an acyl CoA thiolester of variable chain-length with oxaloacetic acid, catalyzed by a citrate synthase (CS). In addition, a 2-methyl citrate dehydratase $(2 \mathrm{MCD})$ is required to catalyze subsequent steps [6]. Therefore, the A. oryzae genome was analyzed for a BGC containing genes encoding those enzymes. MultiGeneBlast [22] analysis (Figure S11) indicated the presence of a single BGC that contains genes encoding a CS and a 2MCD. The respective genes had no PKS in their proximity but were instead surrounded by $\alpha$ and $\beta$ subunits of a fungal FAS. To verify that this gene cluster is the only possible candidate, a manual search of the A. oryzae genome for CS genes was also conducted. A total of five homologues of CS were identified on the A. oryzae genome by using the CS (Bfl2) of the byssochlamic acid BGC (ANF07286) from Byssochlamys fulva as template. The genes in the proximity to these five targets were analyzed in detail. Four of these genes (amino acid sequence identity with Bfl2 between $55.5 \%$ and $11.2 \%$ ) were not close to any recognized types of biosynthetic genes. The fifth gene ( $37.7 \%$ amino acid sequence identity) was the one predicted by MultiGeneBlast. In addition to the 2MCD and FAS subunits various other biosynthetic genes including oxygenases, lactonases and a decarboxylase were found in this region of the genome. Hence, this BGC was considered as the most likely candidate for oryzine biosynthesis (Figure 3).

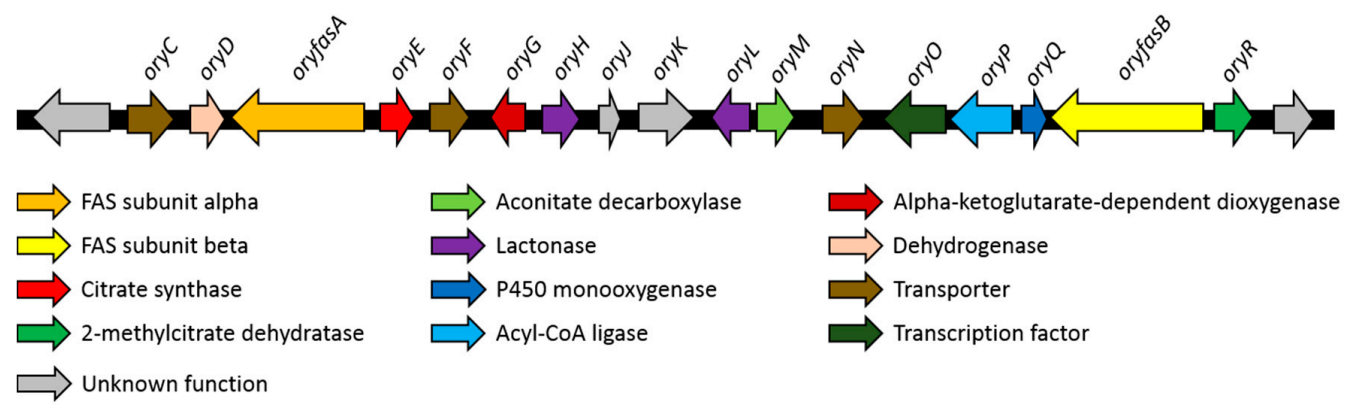

Figure 3. Putative biosynthetic gene cluster of the oryzines.

\subsection{Characteristics of the Putative Oryzine BGC}

The putative oryzine BGC has a size of around $47 \mathrm{~kb}$ and contains 18 predicted genes (Table 1 , Table S1). The two largest genes (oryfas $A$, oryfas $B$ ) encode the $\alpha$ - and $\beta$-subunits of a fungal fatty acid synthase (FAS). Additional copies of FAS genes can be found within the genome of A. oryzae. OryfasA is located at the downstream part of the BGC next to the citrate synthase (oryE) and a putative dehydrogenase (oryD). In contrast, oryfas $B$ is found at the upstream end of the BGC flanked by a $2 \mathrm{MCD}$ (oryR) and a gene encoding a protein with high similarity to sterigmatocystin P450 monooxygenase (ory $Q)$. The short amino acid sequence of OryQ (170 aa) implies a truncation, probably hampering its functionality. Between the two FAS encoding genes additional biosynthetic genes can be identified. OryG is homologous to the $\alpha$-ketoglutarate-dependent taurine dioxygenase (P37610, 31\% identity) and OryH as well as OryL contain a domain that belongs to the lactonase superfamily. OryM encodes a protein related to aconitate decarboxylases, whereas ory $P$ is most likely encodes an acyl-CoA ligase. In addition, multiple putative transporters $(o r y C, o r y F, o r y N)$ and a putative transcription factor (ory $P$ ) can be found. The genes oryJ and oryK cannot be assigned to any known biosynthetic family. 
Table 1. Predicted genes of the oryzine BGC and their proposed function.

\begin{tabular}{|c|c|c|c|}
\hline Gene & $\begin{array}{l}\text { GenBank } \\
\text { Acc. No. }\end{array}$ & $\begin{array}{l}\text { Proposed } \\
\text { Function }\end{array}$ & Closest UniProtKB Hit (Query Coverage/Identity) \\
\hline oryC & XP_023094066 & Transporter & $\begin{array}{c}\text { Sugar transporter STL1, Saccharomyces cerevisiae, } \\
\text { P39932 }(94 \% / 33 \%)\end{array}$ \\
\hline ory $D$ & - & Dehydrogenase & $\begin{array}{c}\text { Histidinol dehydrogenase 1, Bacillus clausii, } \\
\text { Q5WIU9 ( } 99 \% / 56 \%)\end{array}$ \\
\hline oryfas $A$ & XP_001827206 & $\begin{array}{c}\text { Fatty acid } \\
\text { synthase subunit } \\
\text { alpha }\end{array}$ & $\begin{array}{l}\text { Fatty acid synthase subunit alpha, Aspergillus nidulans, } \\
\text { Q5B7V0 }(99 \% / 46 \%)\end{array}$ \\
\hline oryE & XP_001827205 & Citrate synthase & $\begin{array}{c}\text { Citrate synthase, Dictyostelium discoideum, } \\
\text { Q86AV6 }(97 \% / 38 \%)\end{array}$ \\
\hline oryF & XP_001827204 & Transporter & $\begin{array}{c}\text { Efflux pump VrtL, Penicillium aethiopicum, } \\
\text { D7PHY8 (95\%/39\%) }\end{array}$ \\
\hline oryG & XP_001827203 & $\begin{array}{l}\text { Alpha-ketoglut- } \\
\text {-arate dependent } \\
\text { dioxygenase }\end{array}$ & $\begin{array}{c}\text { Alpha-ketoglutarate-dependent sulfonate dioxygenase, } \\
\text { Saccharomyces cerevisiae, Q12358 (88\%/32\%) }\end{array}$ \\
\hline oryH & XP_023094065 & Lactonase & $\begin{array}{c}\text { Gluconolactonase, Zymomonas mobilis, } \\
\text { Q01578 }(52 \% / 28 \%)\end{array}$ \\
\hline oryJ & XP_023094064 & - & Lysine-tRNA ligase, Bacillus cereus, B7JK84 (24\%/30\%) \\
\hline oryK & XP_001827200 & - & $\begin{array}{l}\text { Ankyrin repeat and KH domain-containing protein } \\
\text { mask, Drosophila melanogaster, Q9VCA8 (36\%/27\%) }\end{array}$ \\
\hline oryL & XP_023094061 & Lactonase & $\begin{array}{c}\text { Gluconolactonase, Zymomonas mobilis, } \\
\text { Q01578 (66\%/25\%) }\end{array}$ \\
\hline oryM & XP_001827196 & $\begin{array}{c}\text { Aconitate } \\
\text { decarboxylase }\end{array}$ & $\begin{array}{c}\text { Cis-aconitate decarboxylase, Aspergillus terreus, } \\
\text { Q0C8L3 }(98 \% / 55 \%)\end{array}$ \\
\hline oryN & XP_001827195 & Transporter & $\begin{array}{c}\text { Citrinin biosynthesis cluster MFS transporter Mrr1, } \\
\text { Monascus ruber, A0A161CLJ6 (93\%/48\%) }\end{array}$ \\
\hline oryO & XP_023094060 & $\begin{array}{l}\text { Transcription } \\
\text { factor }\end{array}$ & $\begin{array}{l}\text { Uncharacterized transcriptional regulatory protein } \\
\text { C530.05, Schizosaccharomyces pombe, O59741 (24\%/40\%) }\end{array}$ \\
\hline oryP & - & Acyl-CoA ligase & $\begin{array}{l}\text { Acyl-CoA synthetase family member 3, Homo sapiens, } \\
\text { Q4G176 }(92 \% / 23 \%)\end{array}$ \\
\hline oryQ & - & $\begin{array}{c}\text { P450 } \\
\text { monooxygenase } \\
\text { (truncated) }\end{array}$ & $\begin{array}{c}\text { Probable sterigmatocystin biosynthesis P450 } \\
\text { monooxygenase StcF, Aspergillus nidulans, } \\
\text { Q12609 (82\%/49\%) }\end{array}$ \\
\hline oryfas $B$ & XP_001827193 & $\begin{array}{c}\text { Fatty acid } \\
\text { synthase subunit } \\
\text { beta }\end{array}$ & $\begin{array}{l}\text { Fatty acid synthase subunit beta, Yarrowia lipolytica, } \\
\qquad \text { P34229 (99\%/40\%) }\end{array}$ \\
\hline oryR & XP_001827192 & $\begin{array}{l}\text { 2-Methylcitrate } \\
\text { dehydratase }\end{array}$ & $\begin{array}{c}\text { 2-methylcitrate dehydratase, Escherichia coli, } \\
\text { P77243 }(96 \% / 49 \%)\end{array}$ \\
\hline
\end{tabular}

\subsection{Proposed Biosynthesis of the Oryzines}

With the set of identified biosynthetic genes in hand, a putative biosynthetic pathway can be proposed (Figure 4). The two subunits of the fungal FAS (OryfasA, OryfasB) probably form octenoic acid 5. This fatty acid is most likely activated by the acyl-CoA ligase OryP to give octenyl CoA 6 before the CS (OryE) acts to catalyze condensation with oxaloacetate to form tricarboxylic acid 7. At this stage, two pathways appear feasible. In the first, decarboxylation and concomitant dehydration (OryM), followed by tautomerization gives the diene 9. Reduction of this could give the known metabolite piliformic acid $\mathbf{1 0}$ from the fungus Xylaria mali which has been shown to be derived from FAS-derived octanoic acid and oxaloacetate by feeding studies [28]. On the pathway to 3 and $\mathbf{4}$, however, hydroxylation of the diene $\mathbf{9}$ (OryG) and lactonisation (OryH or OryL) could give oryzine B 4 directly. Final enoyl reduction (OryD) would then give Oryzine A 3. An alternative pathway branching from $\mathbf{7}$ could involve epoxidation to $\mathbf{1 1}$ (OryG) followed by ring closure (OryH or OryL). The resulting diol 12 could be a substrate for the MCDH to give unsaturated alcohol 13. Finally, 
concerted decarboxylation and dehydration (OryM) could give the observed 4. We do not yet have enough experimental evidence to distinguish these possibilities, but the first pathway is preferred due to the proximity to the known metabolite piliformic acid $\mathbf{1 0 .}$

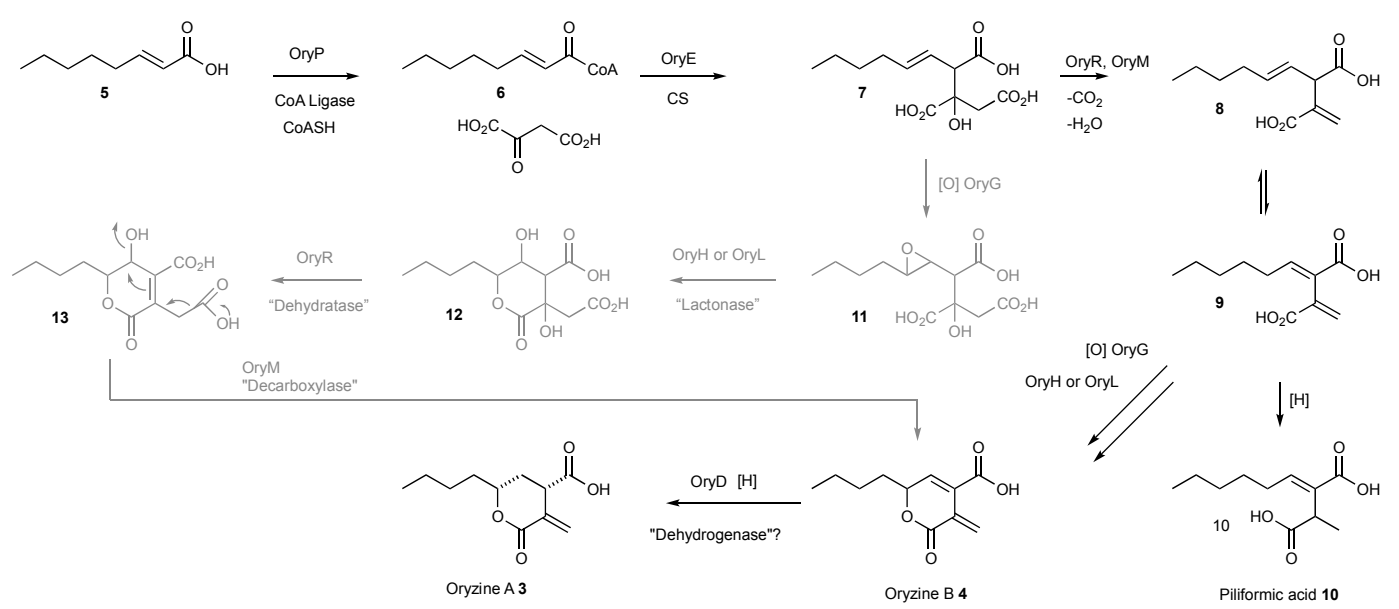

Figure 4. Proposed biosynthetic pathway for oryzine A 3 and B 4.

\section{Discussion}

It is clear that our original genetic engineering experiment in A. oryzae M-2-3 did not give the anticipated result. However, the transformed organism produced two compounds, oryzines A 3 and B 4, in titers significantly higher than untransformed strains of A. oryzae. As various other transformants did not show increased production of oryzines it can be speculated that the regulation of gene expression within the oryzine BGC was influenced by the random insertion of the heterologous expressed tenS gene into the $A$. oryzae genome. Related compounds such as piliformic acid $\mathbf{1 0}$ are known to be derived from fatty acids and oxaloacetate [28]; while the furofuranones 4-epi-ethiosiloide 14, sporothriolide 15 and discosiolide 16, are also thought to be derived from fatty acids and oxaloacetate $[29,30]$. These compounds differ from $\mathbf{3}$ and $\mathbf{1 0}$ by having differing carbon-chain lengths, and by a different lactonisation pattern. It is therefore likely that the oryzines, piliformic acid $\mathbf{1 0}$ and the furofuranones 14-16 are assembled by similar biosynthetic machinery. However, to date, none of these compounds have been linked to any BGC. The presence of a fatty acyl and an oxaloacetyl moiety is also known in the maleidride class of secondary metabolites where a key citrate synthase-type enzyme is responsible for their formation. We thus suspected that the oryzines are a class of hitherto unrecognised maleidrides and the biosynthesis should also require a citrate synthase step.

Based on the BGC prediction, the first steps of oryzine biosynthesis are likely to be similar to those of the elucidated byssochlamic acid (BA 17) biosynthesis (Figure 5) [6]. The main difference is the mode of production of the alkenoic acid: in case of BA $\mathbf{1 7}$ this is produced by a polyketide synthase; but in the case of $\mathbf{3}$ and $\mathbf{4}$ the alkanoic acid is probably produced by a fatty acid synthase. FAS components of fungal BGC are known, but their essential role for the biosynthesis of secondary metabolites has only been partially demonstrated. In case of the aflatoxins, sterigmatocystin and dothistromin the FAS subunits provide the initial hexanoyl starter unit for the PKS, which forms norsolorinic acid 18 [31,32] (Figure 5). A homology search of FAS genes in the genome of A. oryzae indicated the presence of four additional copies of both subunits. Only one of these gene pairs had no biosynthetic genes in their proximity, therefore the respective proteins are likely part of primary metabolism. The second FAS copy belongs to the previously identified aflatoxin BGC [31]. The third homologous pair is nested inside an NRPS gene cluster that shows high similarity to the aspercryptin BGC from A. nidulans which is known to require octanoic acid during its biosynthesis [33]. The last FAS is part of an azaphilone-type BGC similar to those identified from various Monascus and Talaromyces (Penicillium) species [34]. 
The high diversity of FAS containing secondary metabolite gene clusters in A. oryzae is striking and highlights the importance of such proteins for natural product biosynthesis.

The BA 17 system requires a hydrolase encoded by $b f l 1$, presumably to release the polyketide from the PKS at the end of its synthesis [6]. However in the case of fungal FAS a dedicated acyl transferase, which is an integral component, releases the fatty acid at the end of biosynthesis. Interestingly it has been shown that these AT domains can be engineered to release short fatty acids [35]. Consistent with this idea is the fact that the proposed oryzine cluster does not contain a gene homologous to bfl1. Similarly, the BA BGC contains genes which encode proteins responsible for the dimerisation (to form nonadrides such as 17) which are not present in the proposed oryzine BGC; and oryzine biosynthesis requires oxidative steps and thus the oryzine BGC has encoded oxygenases not present in the BA BGC (Figure S12).
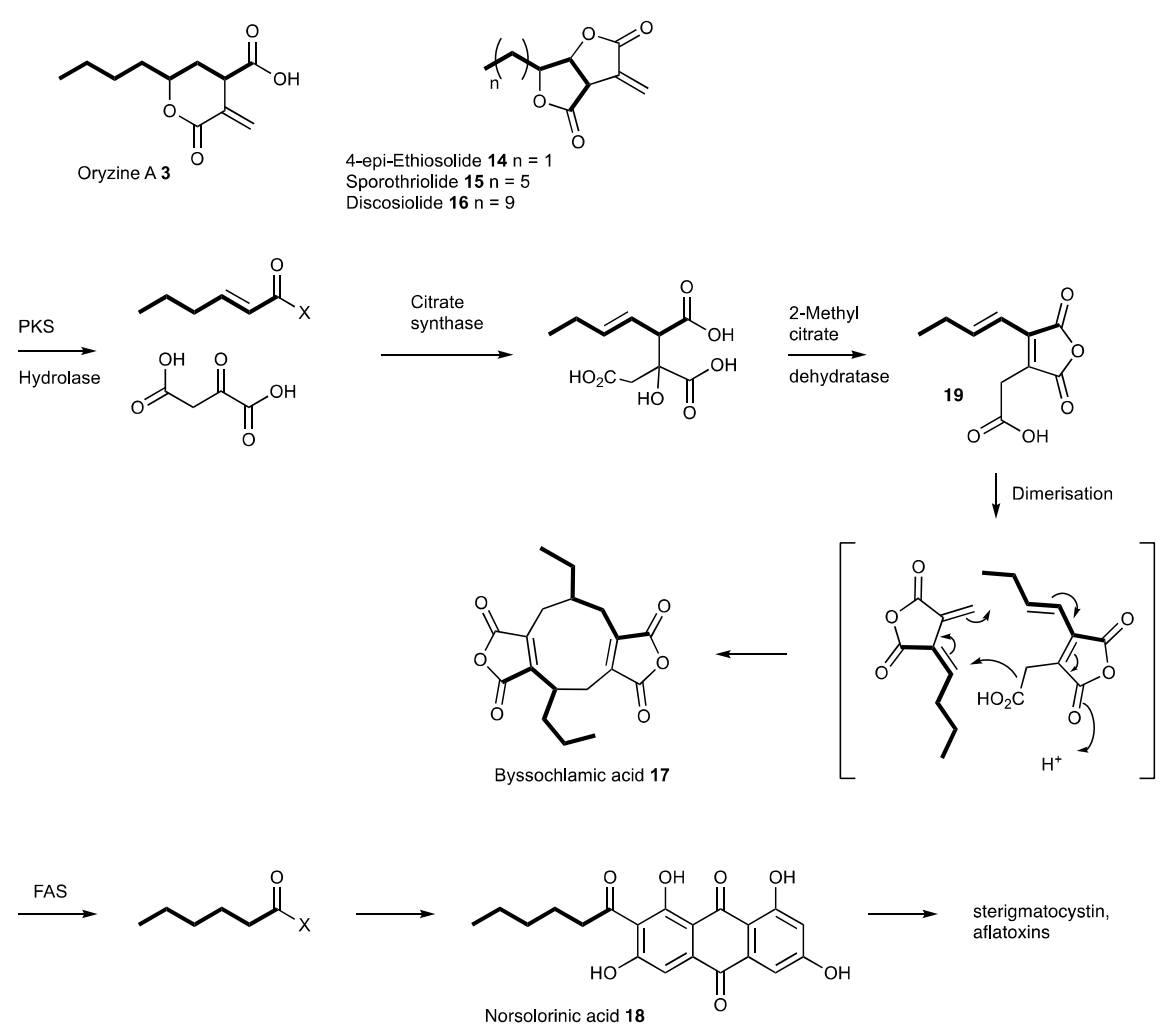

Figure 5. Compounds biosynthetically related to 3 .

It is likely that maleic acid anhydride intermediates such as $\mathbf{1 9}$ (Figure 5) are not formed during oryzine biosynthesis due to the presence of an aconitate decarboxylase, which is not present in the other known maleidride gene clusters. The loss of a carboxyl functionality at C-10 would prevent anhydride formation, which explains the structural differences between the oryzines and the maleic acid anhydrides. In other systems one could imagine oxidations and lactonisations with different regioselectivities leading to the furofuranones 14-16.

Even though only a limited set of biosynthetic steps is necessary to explain the assembly of the oryzines, the BGC seems rather large. However, in order to correctly define the borders of the cluster transcription studies should be conducted. It is also questionable if all predicted genes encode functional proteins. A BGC comparison with A. flavus revealed the presence of a homologous BGC with $>99.5 \%$ similarity (Figure S12), highlighting the potential of A. flavus to produce oryzines as well. Whether these compounds have been overlooked in the past by researchers, or are not produced under the tested conditions or whether small mutations in the A. flavus BGC abolished production of 3 and 4 or closely related compounds must also be evaluated in the future. 


\section{Conclusions}

The oryzines isolated from Aspergillus oryzae constitute a novel class of maleidrides, which are structurally related to furofuranones 14-16. In our previous work we have proven the links between fungal gene clusters by either knockout or heterologous expression in engineered strains of A. oryzae. Here, however, the heterologous expression strategy is obviated by the presence of the genes of interest in the expression host itself; while knockout strategies were frustrated by the low titer of 3 and 4 in untransformed A. oryzae. However, comparison of the BGCs of A. oryzae with the byssochlamic acid gene cluster from $B$. fulva revealed a single candidate cluster containing FAS, citrate synthase, dehydratase, decarboxylase and oxygenase genes, and no other likely BGCs in the A. oryzae genome. The presence of a FAS and a CS in a single cluster and their link to a final product is shown for the first time, adding to our knowledge about fungal biosynthetic pathways. These observations also allow the development of a firm hypotheses for the biosynthesis (and hence the composition of biosynthetic gene clusters) of the furofuranones and related compounds such as piliformic acid 10. Further progress, however, will have to await full genome sequencing of the organisms responsible for the biosynthesis of these compounds. Future work will involve the development of new methods to understand such clusters.

Supplementary Materials: The following are available online at http://www.mdpi.com/2309-608X/4/3/96/s1: Figures S1-S10, 1D and 2D NMR data for 3 and 4; Figure S11, MultiGeneBlast (architecture search) of the byssochlamic acid biosynthetic genes bfpks1, bfl2 and bfl3 against the genomes of Aspergillus oryzae RIB40 and A. flavus NRRL3357; Figure S12, Artemis comparison tool (ACT) analysis between the putative oryzine biosynthetic gene cluster (BGC) of A. flavus (A) and A. oryzae (B) and the byssochlamic acid BGC of Byssochlamys fulva (C); Table S1, Predicted genes and corresponding nucleotide as well as protein sequences of the re-annotated oryzine BGC from A. oryzae RIB40.

Author Contributions: Conceptualization, R.J.C. and T.J.S.; Investigation, Z.W. and E.K.; Writing-Original Draft Preparation, R.J.C. and E.K.; Supervision, R.J.C. and T.J.S.; Project Administration, R.J.C. and T.J.S.; Funding Acquisition, R.J.C. and Z.W.

Funding: This research was funded by EPSRC (Engineering and Physical Sciences research council) grant number EP/F066104/1 and DFG (Deutsche Forschungsgemeinschaft) grant number CO 1328/4-1.

Acknowledgments: The authors thank Jenny Rose and Walid Bakeer for technical assistance. Zahida Wasil Thanks the Government of Pakistan (Higher Education Commission) for funding. We are grateful to Daniel Wibberg for the re-annotation of the $A$. oryzae genomic data.

Conflicts of Interest: The authors declare no conflict of interest.

\section{References}

1. Park, H.S.; Jun, S.C.; Han, K.H.; Hong, S.B.; Yu, J.H. Diversity, Application and synthetic biology of industrially important aspergillus fungi. Adv. Appl. Microbiol. 2017, 100, 161-202. [CrossRef] [PubMed]

2. Pariza, M.W.; Johnson, E.A. Evaluating the safety of microbial enzyme preparations used in food processing: Update for a new century. Regul. Toxicol. Pharmacol. 2001, 33, 173-186. [CrossRef] [PubMed]

3. He, Y.; Wang, B.; Chen, W.; Cox, R.J.; He, J.; Chen, F. Recent advances in reconstructing microbial secondary metabolites biosynthesis in Aspergillus spp. Biotechnol. Adv. 2018, 36, 739-783. [CrossRef] [PubMed]

4. Schor, R.; Schotte, C.; Wibberg, D.; Kalinowski, J.; Cox, R.J. Three previously unrecognised classes of biosynthetic enzymes revealed during the production of xenovulene A. Nat. Commun. 2018, 9, 1963. [CrossRef] [PubMed]

5. Bailey, A.M.; Alberti, F.; Kilaru, S.; Collins, C.M.; De Mattos-Shipley, K.; Hartley, A.J.; Hayes, P.; Griffin, A.; Lazarus, C.M.; Cox, R.J.; et al. Identification and manipulation of the pleuromutilin gene cluster from Clitopilus passeckerianus for increased rapid antibiotic production. Sci. Rep. 2016, 6, 1-11. [CrossRef] [PubMed]

6. Williams, K.; Szwalbe, A.J.; Mulholland, N.P.; Vincent, J.L.; Bailey, A.M.; Willis, C.L.; Simpson, T.J.; Cox, R.J. Heterologous production of fungal maleidrides reveals the cryptic cyclization involved in their biosynthesis. Angew. Chem.-Int. Ed. 2016, 55, 6784-6788. [CrossRef] [PubMed] 
7. Fujii, R.; Minami, A.; Tsukagoshi, T.; Sato, N.; Sahara, T.; Ohgiya, S.; Gomi, K.; Oikawa, H. Total biosynthesis of diterpene aphidicolin, a specific inhibitor of dna polymerase $\alpha$ : Heterologous expression of four biosynthetic genes in Aspergillus oryzae. Biosci. Biotechnol. Biochem. 2011, 75, 1813-1817. [CrossRef] [PubMed]

8. Machida, M.; Yamada, O.; Gomi, K. Genomics of Aspergillus oryzae: Learning from the history of koji mold and exploration of its future. DNA Res. 2008, 15, 173-183. [CrossRef] [PubMed]

9. Rank, C.; Klejnstrup, M.L.; Petersen, L.M.; Kildgaard, S.; Frisvad, J.C.; Held Gotfredsen, C.; Ostenfeld Larsen, T. Comparative chemistry of Aspergillus oryzae (RIB40) and A. flavus (NRRL 3357). Metabolites 2012, 2, $39-56$. [CrossRef] [PubMed]

10. Shaaban, M.; El-Metwally, M.M.; Nasr, H. A new diketopiperazine alkaloid from Aspergillus oryzae. Nat. Prod. Res. 2014, 28, 86-94. [CrossRef] [PubMed]

11. Ren, R.; Chen, C.-J.; Hu, S.-S.; Ge, H.-M.; Zhu, W.-Y.; Tan, R.-X.; Jiao, R.-H. Drimane Sesquiterpenoids from the Aspergillus oryzae QXPC-4. Chem. Biodivers. 2015, 12, 371-379. [CrossRef] [PubMed]

12. Liu, L.; Bao, L.; Wang, L.; Ma, K.; Han, J.; Yang, Y.; Liu, R.; Ren, J.; Yin, W.; Wang, W.; et al. Asperorydines A-M: Prenylated Tryptophan-Derived Alkaloids with Neurotrophic Effects from Aspergillus oryzae. J. Org. Chem. 2018, 83, 812-822. [CrossRef] [PubMed]

13. Lee, C.Z.; Liou, G.Y.; Yuan, G.F. Comparison of Aspergillus flavus and Aspergillus oryzae by amplified fragment length polymorphism. Bot. Bull. Acad. Sin. 2004, 45, 61-68.

14. Machida, M.; Asai, K.; Sano, M.; Tanaka, T.; Kumagai, T.; Terai, G.; Kusumoto, K.I.; Arima, T.; Akita, O.; Kashiwagi, Y.; et al. Genome sequencing and analysis of Aspergillus oryzae. Nature 2005, 438, 1157-1161. [CrossRef] [PubMed]

15. Seshime, Y.; Juvvadi, P.R.; Kitamoto, K.; Ebizuka, Y.; Nonaka, T.; Fujii, I. Aspergillus oryzae type III polyketide synthase CsyA is involved in the biosynthesis of 3,5-dihydroxybenzoic acid. Bioorganic Med. Chem. Lett. 2010, 20, 4785-4788. [CrossRef] [PubMed]

16. Marui, J.; Ohashi-Kunihiro, S.; Ando, T.; Nishimura, M.; Koike, H.; Machida, M. Penicillin biosynthesis in Aspergillus oryzae and its overproduction by genetic engineering. J. Biosci. Bioeng. 2010, 110, 8-11. [CrossRef] [PubMed]

17. Marui, J.; Yamane, N.; Ohashi-Kunihiro, S.; Ando, T.; Terabayashi, Y.; Sano, M.; Ohashi, S.; Ohshima, E.; Tachibana, K.; Higa, Y.; et al. Kojic acid biosynthesis in Aspergillus oryzae is regulated by a Zn(II)2Cys6transcriptional activator and induced by kojic acid at the transcriptional level. J. Biosci. Bioeng. 2011, 112, 40-43. [CrossRef] [PubMed]

18. Gomi, K.; Iimura, Y.; Hara, S. Integrative Transformation of Aspergillus oryzae with a Plasmid Containing the Aspergillus nidulans argB Gene. Agric. Biol. Chem. 1987, 51, 2549-2555. [CrossRef]

19. Bakeer, W. Overexpression of Secondary Metabolism Genes from Magnaporthe grisea and Beauveria bassiana. Ph.D. Thesis, University of Bristol, Bristol, UK, 2011.

20. Stanke, M.; Steinkamp, R.; Waack, S.; Morgenstern, B. Augustus: A web server for gene finding in eukaryotes. Nucleic Acids Res. 2004, 32, W309-W312. [CrossRef] [PubMed]

21. Ter-Hovhannisyan, V.; Lomsadze, A.; Chernoff, Y.O.; Borodovsky, M. Gene prediction in novel fungal genomes using an ab initio algorithm with unsupervised training. Genome Res. 2008, 18, 1979-1990. [CrossRef] [PubMed]

22. Medema, M.; Takano, E.; Breitling, R. Detecting Sequence Homology at the Gene Cluster Level with MultiGeneBlast. Mol. Biol. Evol. 2013, 30, 1218-1223. [CrossRef] [PubMed]

23. Carver, T.J.; Rutherford, K.M.; Berriman, M.; Rajandream, M.A.; Barrell, B.G.; Parkhill, J. ACT: The Artemis comparison tool. Bioinformatics 2005, 21, 3422-3423. [CrossRef] [PubMed]

24. Fisch, K.M.; Bakeer, W.; Yakasai, A.A.; Song, Z.; Pedrick, J.; Wasil, Z.; Bailey, A.M.; Lazarus, C.M.; Simpson, T.J.; Cox, R.J. Rational Domain Swaps Decipher Programming in Fungal Highly Reducing Polyketide Synthases and Resurrect an Extinct Metabolite. J. Am. Chem. Soc. 2011, 133, 16635-16641. [CrossRef] [PubMed]

25. Heneghan, M.N.; Yakasai, A.A.; Williams, K.; Kadir, K.A.; Wasil, Z.; Bakeer, W.; Fisch, K.M.; Bailey, A.M.; Simpson, T.J.; Cox, R.J.; et al. The programming role of trans-acting enoyl reductases during the biosynthesis of highly reduced fungal polyketides. Chem. Sci. 2011, 2, 972-979. [CrossRef] 
26. Szwalbe, A.; Williams, K.; O’Flynn, D.; Bailey, A.; Mulholland, N.; Vincent, J.; Willis, C.; Cox, R.; Simpson, T. Novel nonadride, heptadride and maleic acid metabolites from the byssochlamic acid producer Byssochlamys fulva IMI 40021-an insight into the biosynthesis of maleidrides. Chem. Commun. 2015, 51, 17088-17091. [CrossRef] [PubMed]

27. Williams, K.; Szwalbe, A.; Dickson, C.; Desson, T.; Mulholland, N.; Vincent, J.; Clough, J.; Bailey, A.; Butts, C.; Willis, C.; et al. Genetic and chemical characterisation of the cornexistin pathway provides further insight into maleidride biosynthesis. Chem. Commun. 2017, 53, 7965-7968. [CrossRef] [PubMed]

28. Chesters, N.C.J.E.; O'Hagan, D. Biosynthesis of the fungal metabolite, piliformic acid (2-hexylidene-3-methylsuccinic acid). J. Chem. Soc. Perkin. Trans. 1 1997, 827-834. [CrossRef]

29. Krohn, K.; Ludewig, K.; Aust, H.-J.; Dräger, S.; Schulz, B. Biologically active metabolites from fungi. 3. Sporothriolide, discosiolide, and 4-epi-ethisolide New furofurandiones from Sporothrix sp., Discosia sp., and Pezicula livida. J. Antibiot. (Tokyo) 1994, 47, 113-118. [CrossRef] [PubMed]

30. Surup, F.; Kuhnert, E.; Lehmann, E.; Heitkämper, S.; Hyde, K.D.; Fournier, J.; Stadler, M. Sporothriolide derivatives as chemotaxonomic markers for Hypoxylon monticulosum. Mycology 2014, 5, 110-119. [CrossRef] [PubMed]

31. Hitchman, T.S.; Schmidt, E.W.; Trail, F.; Rarick, M.D.; Linz, J.E.; Townsend, C.A. Hexanoate synthase, a specialized type I fatty acid synthase in aflatoxin B1biosynthesis. Bioorg. Chem. 2001, 29, $293-307$. [CrossRef] [PubMed]

32. Mahanti, N.; Bhatnagar, D.; Cary, J.W.; Joubran, J.; Linz, J.E. Structure and function of fas-1A, a gene encoding a putative fatty acid synthetase directly involved in aflatoxin biosynthesis in Aspergillus parasiticus. Appl. Environ. Microbiol. 1996, 62, 191-195. [PubMed]

33. Chiang, Y.; Ahuja, M.; Oakley, C.; Entwistle, R.; Asokan, A.; Zutz, C.; Wang, C.; Oakley, B. Development of Genetic Dereplication Strains in Aspergillus nidulans Results in the Discovery of Aspercryptin. Angew. Chem. Int. Ed. 2015, 55, 1662-1665. [CrossRef] [PubMed]

34. Chen, W.; Chen, R.; Liu, Q.; He, Y.; He, K.; Ding, X.; Kang, L.; Guo, X.; Xie, N.; Zhou, Y.; et al. Orange, red, yellow: Biosynthesis of azaphilone pigments in Monascus fungi. Chem. Sci. 2017, 8, 4917-4925. [CrossRef] [PubMed]

35. Zhu, Z.; Zhou, Y.; Krivoruchko, A.; Grininger, M.; Zhao, Z.; Nielsen, J. Expanding the product portfolio of fungal type I fatty acid synthases. Nat. Chem. Biol. 2017, 13, 360-362. [CrossRef] [PubMed] 